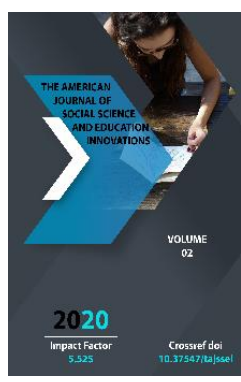

Copyright: Original content from this work may be used under the terms of the creative commons attributes 4.0 licence.

\section{Improving The Professional Competence Of The Teacher In The Course Of Project Activities Of Students}

\author{
Shavkat Ergashevich Kurbanov \\ Doctor Of Pedagogical Sciences, Professor, Institute Of Pedagogical Innovations, \\ Management Of Vocational Education And Training And Retraining Of Teachers, Tashkent, \\ Uzbekistan
}

Nozima Ravshanovna Pulatova

People Named After Abdulla Avloni Postdoctoral Fellow Of The Institute Of Retraining And Advanced Training Of Education And Leadership, Tashkent, Uzbekistan

\title{
ABSTRACT
}

The article is devoted to theoretical aspects of formation of professional competence ofteachers through joint design activities with students. The Genesis of the development of theconcept of "professional competence" based on the analysis of various sources is discussed.The term "professional competence" is considered and its main components are made. Thearticle high lights project activities in the modern paradigm of education.

\section{KEYWORDS}

Professional competence, project activity, individual, teacher, educationalprocess.

\section{INTRODUCTION}

Modern education makes high demands on the teacher. A teacher should be distinguished by such features as creativity, the ability to creatively solve various pedagogical problems, willingness to cooperate with both colleagues and students and their parents, tolerance, emotional stability, ability to resolve conflict situations, willingness to constant selfeducation and self-development. The teacher is the guarantor of the tasks set by society before education. Therefore, one of the main tasks of modernization of education is to increase the professionalism of teachers as a factor in improving the quality of education. All 
this leads to the construction of a new educational space in which the teacher is located.

\section{MATERIAL AND METHODS}

The term "professional competence" began to be used at the end of the last century, and the concept itself was considered for a long time by scientists studying the problem of pedagogical activity. So, for example, V.N. Vvedensky considered the term "professional competence" as integrative, which included such concepts as "professionalism", "qualification", "professional abilities", etc. Questions of professional and pedagogical competence are also reflected in the works of V.A. Slastenin, N.I. Zaprudsky, E.V. Bondarevskaya and others

The problems of preparing a competent teacher were dealt with by V.A. Bolotov, A.V. Farmstead, etc. A.V. Khutorskoy discusses pedagogical competence from the perspective of a new approach to the construction of educational standards [2].

\section{RESULTS AND DISCUSSION}

In his works, L.G. Semushina, E.F. Seer, A.K. Markova, while exploring the structure of professional competence, notes that its components are special knowledge, skills, as well as a combination of significant personal characteristics and value orientations. N.V. Kuzmina and L.M. Mitin among the professional competencies of the teacher distinguish: the ability to act with restrictions and prescriptions; knowledge, skills, skills of the teacher, methods and techniques used by him in work; value orientations, motives, relationships; knowledge and experience in various fields; level of professionalism, creativity; personal qualities that allow you to effectively solve problems.

Being an integral characteristic, the professional competence of the teacher can be expressed in various actions: creativity and creativity, the ability to quickly navigate and act in non-standard situations, the successful implementation of new technologies and programs, creating conditions for the personal development of the child. V.A. Slastenin in the concept of "professional competence" includes three main aspects:

- Problem-practical, when the teacher adequately recognizes and understands the situation that has arisen, effectively and successfully fulfills the goals and objectives in this situation;

- Semantic - the tasks that have arisen are carried out in a wider sociocultural context;

- Value - the ability to correctly assess the situation, goals and objectives from the standpoint of generally valid values.

A.M. Novikov, considering the concept of professional competence, says that it has a supra-professional character. The main components that make up the foundation of professional competence are personality traits such as responsibility, autonomy, the ability to make decisions and bear responsibility for them, to constantly learn and develop; flexible thinking, ability to think abstractly and communicative qualities: ability to dialogue, sociability, ability to interact.

The study of professional competence is most fully reflected in the works of A.K. Markova, who defines professional competence as the interconnection of mental qualities and conditions, giving a person engaged in professional activities, the opportunity to 
show independence, responsibility ("effective competence"); as the ability to perform certain labor functions [1].

Thus, it is possible to call a professionally competent teacher who carries out pedagogical activities at a fairly high level and achieves high levels in the training and education of students.

The project activity is precisely aimed at optimizing the professional competence of the teacher, the ability to work in innovative conditions. One of the tasks of the modern education system is to create conditions for quality education. To achieve this goal, a competency-based approach is implemented, which is a triad of "ability to act," "ability to be," and "ability to live."

A teacher who does not have creative thinking, does not know how, and does not strive for constant self-development and self-education, never educates a creative person. The student should not remain an inert consumer of educational services; in the new paradigm of education, he is an active creator who knows how to pose problems and find solutions, i.e. the student is an active participant in the educational process. The educational system is aimed at the formation of a new personality, capable of self-development throughout life. The idea of developing a student's personality comes to the fore.

The method of project activity is mainly used to develop general educational skills, create conditions for independent growth of knowledge and the formation of motivation for self-development.

Departing from traditional knowledge, skills of skillful learning, the teacher in project activities refuses the role of leader and becomes the position of cooperation and partnership in joint activities.

The main role of the teacher working on the project method is the ability to understand the child as a researcher who has his own opinion, puts forward his hypotheses and assumptions. By unobtrusively controlling the process of the project, the teacher indirectly affects the student, helping him to come to the conclusion about what the wrong actions he did in the project, how to fix them and what conclusions should be checked again.

Working in this sense, the student gains a sense of independence, which the teacher needs to constantly maintain, thereby increasing the child's motivation to learn.

In implementing the method of project activity, the teacher must also remember the main pedagogical goal, which is to form the various key competencies of students. As a consultant and student assistant, the teacher, in the course of the implementation of project activities, implements an individual approach to each student. Carrying out his own project, the child solves another practical and research task, each time mastering new knowledge.

\section{CONCLUSIONS}

Using the design method dramatically changes almost all parts of the educational process, the type of relationship between the teacher and the student, the assessment system. It is the teacher's attitude to creativity, his professionalism is that main resource, without which it is impossible to fulfill the new federal state educational standards in an educational organization, and therefore, it is impossible to educate a new person with a certain set of competencies. 


\section{REFERENCES}

Performance. Journal of Social Work and Science Education, 1(1), 58-69.

1. Markova A.K. The psychology of professionalism. M.: Intern. humanity. Knowledge Fund, 1996. 308 p.

2. Khutorskoy A.V. The definition of general subject content and key competencies as a characteristic of a new approach to the construction of educational standards [Electronic resource]. Access mode: http: //xn-h1am1a.xn--p1ai/journal/2011/ EidosVestnik 2011-103-Khutorskoy. pdf (accessed date: 01/31/2020).

3. Ravshanovna, P. N., \& Abdurashidovich, K. A. (2019). ROLE OF INNOVATION IN SCHOOL DEVELOPMENT. European Journal of Research and Reflection in Educational Sciences Vol, 7(12).

4. Rustamiy, S. (2018). Typological peculiarties of science of balaghah, rhetoric and stylistics. The Light of Islam, 2018(1), 16.

5. Rustamiy, S. A. (2020). Content of components of the science balagat. ACADEMICIA: An International Multidisciplinary Research Journal, 10(10), 1332-1337.

6. Karabaevna, I. Z., Riskulova, K., Ubaydullaevich, A. M., Turaevna, I. Y., \& Ravshanovna, P. N. (2020). THE ROLE OF ELECTRONIC PEDAGOGICAL TOOLS IN HIGHER EDUCATION. Journal of Critical Reviews, 7(5), 396-398.

7. Odilov, B. A., \& Karimov, N. R. (2020). ANALYSIS OF TARGETED RESEARCH IN 2030 YEARS OF THE XX CENTURY. PalArch's Journal of Archaeology of Egypt/Egyptology, 17(6), 8887-8893.

8. Murkatik, K., Harapan, E., \& Wardiah, D. (2020). The Influence of Professional and Pedagogic Competence on Teacher's 